\title{
Mentální dovednosti českých sportovců: validační studie české verze dotazníku 0MSAT-3*
}

\section{Mental skills among Czech athletes: Validation of the Czech version of OMSAT-3* questionnaire}

\author{
Michal Vičar', Hana Hřebíčková \\ ${ }^{1}$ Fakulta sportovních studii, Masarykova univerzita, Brno \\ ${ }^{2}$ Fakulta tělesné kultury, Univerzita Palackého, Olomouc
}

\begin{abstract}
Abstrakt
Ottawský dotazník mentálních dovedností ve sportu (Ottawa Mental Skills Assessment Tool, OMSAT-3*, Durand-Bush, Salmela, \& Green-Demers, 2001) je diagnostický nástroj, který se ve světě hojně využívá k posouzení kvality mentálních dovedností profesionálních i amatérských sportovcủ. Článek se zabývá vznikem české verze.

OMSAT-3* obsahuje celkem čtyřicet osm otázek. Zaměřuji se na dvanáct mentálních dovedností rozdělených do tři skupin - základní dovednosti (sebedůvěra, odhodlání a stanovování cílü), psychosomatické dovednosti (reakce na stres, zvládání strachu, relaxace a aktivace) a kognitivní dovednosti (zaměření pozornosti, opětovné zaměření pozornosti, imaginace, mentální trénink a plánování soutěže či zápasu).

Česká verze dotazníku byla verifikovaná na sportovcích ( $n$ - 254) ve věkovém rozmezí 11-42 let, kteři byli zaměřeni na 26 sportovních disciplín a měli různou výkonnostní úroveň. Reliabilita škál byla potvrzena u stanovování cílů, sebedưvěry, odhodlání, aktivace, zaměřenípozornosti, plánování soutěže a mentálního tréninku. U sportovně zkušenějších jedinců byla prokázána reliabilita škály i v prípadě reakce na stres. Zbývající dimenze (relaxace, zvládání strachu, imaginace a opětovné zaměření pozornosti) vykázaly príliš nízkou vnitřní konzistenci. Validita české verze kanadského dotazníku ani jeho faktorová struktura tak nebyla potvrzena. Na základě rozboru nedostatků posuzovaného překladu byl navržen upravený OMSAT-3* - modifikovaná verze.
\end{abstract}

\begin{abstract}
The Ottawa Mental Skills Assessment Tool, OMSAT-3*, (Durand-Bush, N., Salmela, J. H., \& GreenDemers, I., 2001) is a dialogic tool used all around the world to assess the quality of mental skills of both professional and amateur athletes. This article deals with translation and formation of a Czech version. It analyses the findings related to sports talent with an emphasis on sports talent identification and mental skills.

OMSAT-3* is comprised of forty-eight questions. The questionnaire focuses on twelve psychological characteristics of mental skills divided into three groups - Foundation skills (self-confidence, commitment and goal-setting), Psychosomatic skills (stress control, fear control, relaxation and activation) and Cognitive skills (focusing, refocusing, imagery, mental practise and competition planning).

The Czech version of the questionnaire was administrated to athletes ( $n$-254) aged between 11 and 42 years from 26 sport disciplines of various performance levels. The scales reliability was verified in goal-setting, self-confidence, commitment, activation, focusing, competition planning and mental practise, with population more experienced in sport also in stress control. The remaining dimensions (relaxation, fear control, imagery and refocusing) show too low internal consistency. Neither the validity of the Czech version of the questionnaire nor its factor structure were therefore confirmed. Based on an analysis of the translation deficiencies, a new Czech version of the OMSAT-3* questionnaire was created.
\end{abstract}


Klíčová slova: translace, standardizace dotazníku, OMSAT-3*, sportovní talent, mentální dovednosti, psychodiagnostika

Keywords: translation, questionnaire standardisation, OMSAT-3*, sports talent, mental skills, psychodiagnostics

\section{ÚVOD}

Je zřejmé, že na vrcholové úrovni sportu hrají konkrétní fyzické předpoklady velmi významnou roli, např. výška u basketbalu nebo aerobní kapacita u vytrvalostních atletů. Na druhou stranu existuje celá řada vysokých basketbalistů, kteří nikdy nedosáhnou profesionální úrovně, a z běžců s výbornou aerobní kapacitou se nestanou špičkoví běžci. Rozhodující úlohu často hrají psychické faktory. Proto řada vědeckých prací (např́klad Horn, 2002; Orlick \& Partington, 1988; Orlick, 1996; Vealey, 2007; Weinberg \& Gould, 2011) zkoumá psychické schopnosti a mentální dovednosti, které se vyskytují u vrcholových sportovců. Porovnává šampiony s těmi méně úspěšnými s cílem odhalit, proč někteří jedinci vynikají.

Diagnostikovat mentální dovednosti ve sportu je poměrně náročné. V českém prostředí neexistuje spolehlivý nástroj pro jejich zjištování. Ve světě je velmi rozšířeným nástrojem k posouzení těchto vlastností Ottawský dotazník mentálních dovedností ve sportu-3* OMSAT-3* (Ottawa Mental Skill Assassment Tool-3*, Durand-Bush, Salmela \& Green-Demers; 2001). Právě jeho překladem do českého jazyka a posouzením reliability a obsahové validity v rámci širšího procesu jeho standardizace se zabývá tento text.

\section{MENTÁLNÍ DOVEDNOSTI}

Mentální dovednosti jsou psychické vlastnosti sportovce, které do značné míry určují sportovní výkon i výkonnost jedince. Schmidt (1991) je definuje jako adaptivní organizované sekvence kognitivních procesů, u jedince vytvořených a procvičovaných za účelem dosažení optimálního výsledku. Podle Lesyka (1998) jsou trénovatelné a jejich zdokonalení vede ve sportu k lepším výkonům. To potvrzují i další autoři (např. Curtis, 1987; Gould, Guinan, Greenleaf, Medbery a Peterson, 1999; Greenleaf, Gould a Dieffenbacher, 2001; Harris \& Harris, 1984; Mahoney, 1987, Orlick \& Partington, 1988; 1998; Krane \& Williams, 2001; Vealey, 2007; Weinberg \& Gould, 2011; u nás Hřebíčková, 2013), když konstatují, že mentální dovednosti hrají velmi významnou úlohu při dosahování prvotřídních výkonů ve sportu. Durrand-Bush a Salmela (2001) pak tvrdí, že jejich rozvoj do značné míry podmiňuje rozvoj sportovního talentu obecně. Někteří autoři (např. Baker, Schrorer \& Cobley, 2012; Abbot \& Collins, 2004; Vičar \& Válková, 2014, Vičar, Protic \& Válková, 2014) dokonce považují některé mentální dovednosti za součást talentu a doporučují, aby jejich posouzení bylo součástí jeho identifikace.

\section{POPIS OMSAT A JEHO DIMENZÍ}

První verze dotazníku OMSAT-1 (Salmela, 1992) se skládala ze 114 položek, které měřily 14 mentálních dovedností za využití pětistupňové likertovské škály. Byla vytvořena Salmelou (1992) na základě široké rešerše dosavadních výzkumů a znalostí o mentálních dovednostech a jejich vlivu na sportovní talent a výkonnost. Salmela vycházel zejména z prací Ericssona a Faivra (1988) a Kruhového modelu vrcholové výkonosti (Wheel of Excellence) Orlicka a Partingtona (1988), 
popisujícího stěžejní psychické dovednosti využívané ve sportu. Po odhalení nedostatků první verze OMSAT byl dotazník opakovaně přepracován, nejprve Botou (1993; OMSAT-2; 71 položek, 12 mentálních dovedností), posléze Salmelou a Durand-Bushovou (1995; OMSAT-3; 85 položek, 12 mentálních dovedností). V OMSAT-3 byly otázky seskupeny podle jednotlivých mentálních dovedností a předcházela jim jejich definice. Oproti tomu OMSAT-3* (Durand-Bush, Salmela, \& Green-Demers, 2001) má pořadí otázek náhodné a definice mentálních dovedností neobsahuje. Rovněž bylo na základě faktorové analýzy vyřazeno 37 položek s nízkou faktorovou zátěži či chybnou formulací.

OMSAT-3* obsahuje celkem čtyřicet osm otázek a zaměřuje se na dvanáct mentálních dovedností (v závorce kurzívou uvádíme původní anglické termíny) rozdělených do tří skupin dovedností. Má následující strukturu:

\section{A. Základní dovednosti (fundamental skills):}

1. sebedůvěra (self-confidence),

2. stanovování cílů (goal setting),

3. odhodlání (commitment).

B. Psychosomatické dovedností (psychosomatic skills):

4. reakce na stres (stress reaction),

5. zvládání strachu (fear control),

6. relaxace (relaxation),

7. aktivace (activation).

C. Kognitivní dovedností (cognitive skills):

8. zaměření pozornosti (focusing),

9. opětovné zaměření pozornosti (refocusing)

10. imaginace (imagery),

11. mentální trénink (mental practice),

12. plánování soutěže (competition planning).

Tato dvoustupňová struktura byla potvrzená pomocí konfirmativní faktorové analýzy (více viz Durand-Bush, Salmela, \& Green-Demers, 2001). Odpovědi se zaznamenávají na sedmibodovou škálu v rozmezí „rozhodně souhlasím“-„rozhodně nesouhlasím“ se střední hodnotou „ani nesouhlasím, ani souhlasím“. OMSAT-3* zahrnuje demografické otázky týkající se věku respondenta, pohlaví, sportovní disciplíny, nejvyššího dosaženého vzdělání, nejvyšší dosažené výkonnostní úrovně v jeho sportu a současné výkonnostní úrovně.

Výzkumný vzorek původní kanadské verze OMSAT-3* (R-335) zahrnuje sportovce na různých úrovních výkonnosti (elitní - mezinárodní, výkonnostní, amatérské), jež byly vybrány z 35 sportovních odvětví. Věkový rozptyl sportovců je 9-42 let, věkový průměr 19,6 rokủ. Autoři konstatují, že i pro devítileté sportovce byl dotazník dostatečně srozumitelný a že je využitelný v podstatě pro kterýkoliv sport. Zastoupení mužů ve vzorku bylo 175, žen 160. Navazující výzkum Stevensona (1999) neprokázal statisticky významné rozdíly mezi muži a ženami v úrovni a v používání mentálních dovedností v Kanadě ( $\mathrm{R}$ - 121 mužů, 128 žen ve věku 14-19 let).

Dotazník původně vznikl v angličtině, dále byl přeložen do rumunštiny (Craicun, 2009; Craicun, Dobosi \& Rusu, 2009), portugalštiny (Vianna \& Newton, 2005), francouzštiny (Fournier, Bernier, \& Durand-Bush, 2006) či arabštiny (Noômen, Mohamed, Nasri, \& Brahim, 2015). Ve všech překladech byla potvrzena jak vysoká reliabilita metody, tak faktorová struktura, což podtrhuje kvalitu tohoto nástroje. Dotazník byl v daných zemích využit k řadě výzkumů jak ve sportovní oblasti, např. ve fotbalu (Vazini Taher \& Shahbazi, 2013), házené (Shahbazi, Rahimizadeh, Rajabi, \& Abdolmaleki , 2011), volejbalu (Pashabadi et al., 2011) nebo u elitních sportovců obecně (Guelmami, Hamrouni, \& Agrébi, 2014; Salmela, Monfared, Mosayebi, \& Durand-Bush, 2009), tak také v armádě (Hammermeister, Pickering, \& Ohlson, 2009). 


\section{METODIKA}

Cílem výzkumu bylo přeložit a zahájit standardizaci kanadského dotazníku OMSAT-3*. Dlouhodobým cílem je vytvoření české verze dotazníku OMSAT-3*, jehož psychometrické hodnoty by byly srovnatelné s kanadským originálem.

Výzkumný design se skládá ze 2 částí (převod OMSAT-3* a posuzování české verze OMSAT-3*) a z celkem 17 dílčích kroků (Obr. 1: Výzkumný design standardizace dotazníku OMSAT-3* do českého jazyka.1. krok: Překlad dotazníku do českého jazyka), vedoucích k návrhům modifikace dotazníku. Psychometrické vlastnosti dotazníku - především reliabilita jako vnitřní konzistence, vhodnost položek pro tvorbu škál, vzájemná korelace položek odkazujících na validitu - byly zpracovány za pomocí statistických procedur v programu SPSS 20.0 (IBM Corp., Armonk, NY, USA).

\section{Design prekladu}

$\mathrm{V}$ procesu translace a retranslace jsme postupovali podle návodů dokumentovaných Banvillem, Desrosiersem a Genet-Voletem (2000) a především Vallerandem (1989). V rámci celého procesu translace a retranslace a diskusí byla také následována doporučení, která na počátku devadesátých let zformulovala komise psychologů, z níž se ustavila Mezinárodní testovací komise (International Test Comission, 2010, přeloženo Urbánkem, Denglerovou a Širučkem, 2011). Tato vodítka mají za cíl zajistit především obsahovou validitu položek a konstruktovou validitu dotazníku v novém jazyce.

Procesu převodu dotazníku se účastnila řada překladatelů. Uvádíme jejich jazykovou úroveň dle Společného evropského referenčního rámce (Common European Framework of Reference for Languages, 2012) vytvořeného Radou Evropy. Všichni překladatelé splňovali úroveň určenou jako C1 či C2. Složení týmu je popsáno v Tabulce 1.

Tab. 1: Složení překladatelského týmu

\begin{tabular}{|c|l|c|}
\hline $\begin{array}{c}\text { Označení } \\
\text { překladatele }\end{array}$ & Poznámka & Jazyková úroveň \\
\hline A & kvalitně jazykově vybavený sportovní psycholog & $\mathrm{C} 1$ \\
\hline B & profesionální překladatel z oblasti sportu & $\mathrm{C} 2$ \\
\hline C & profesionální překladatel & $\mathrm{C} 2$ \\
\hline D & hlavní autor práce, jazykově vybavený sportovní psycholog & $\mathrm{C} 1$ \\
\hline E & profesionální překladatel - rodilý mluvčí & $\mathrm{C} 2$ \\
\hline F & profesionální překladatel & $\mathrm{C} 2$ \\
\hline G & jazykově vybavený pracovník z oblasti psychologie sportu & $\mathrm{C} 1$ \\
\hline H & profesionální překladatel & $\mathrm{C} 2$ \\
\hline I & jazykově vybavený akademický pracovník z oblasti psychologie & $\mathrm{C} 1$ \\
\hline
\end{tabular}




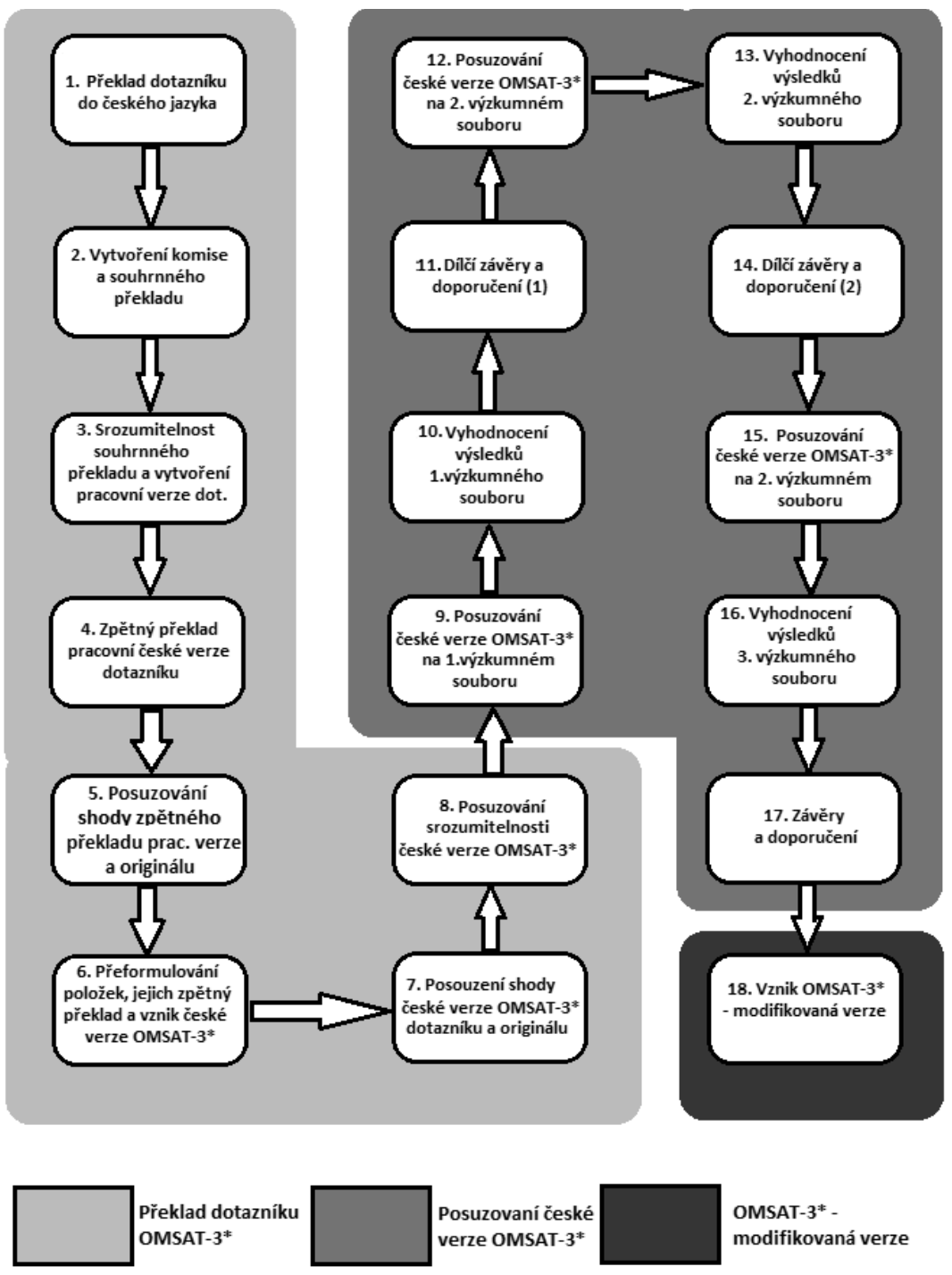

Obr. 1: Výzkumný design standardizace dotazníku OMSAT-3* do českého jazyka.

V následném textu dokumentujeme, na které činnosti daná osoba (označená velkým písmenem) participovala. Design překladu obsahoval celkem osm na sebe navazujících kroků. Tabulka 2 znázorňuje průběh překladu na vybraných otázkách.

\section{1. krok: Překlad dotazníku do českého jazyka}

K překladu byla vybrána anglická verze dotazníku OMSAT-3 (Durrand-Bush, 1995), která obsahuje 85 otázek. Tato starší verze dotazníku byla zvolena z toho důvodu, že některé položky vyřazené kanadskými autory se v českém socio-kulturním kontextu mohly ukázat jako více validní. Dotazník byl přeložen do češtiny nezávisle na sobě překladateli A, B a $\mathbf{C}$.

2. krok: Vytvoření komise a souhrnného překladu

Překladatelé A, B a C spolu s hlavním autorem textu (D) vytvořili komisi. Ta po řízené diskusi nad rozdílnostmi $\mathrm{v}$ překladech sestavila souhrnný překlad. Bylo přitom přihlédnuto $\mathrm{k}$ míře shody mezi jednotlivými překlady. Pokud například některé části položky přeložili dva překladatelé totožně, byla tato pasáž upřednostněna ve výsledné podobě před verzí třetího překladatele. 
3. krok: Posouzení srozumitelnosti souhrnného překladu a vytvoření pracovní české verze dotazníku Souhrnný překlad byl v pilotní studii posouzen především z hlediska srozumitelnosti nezávislými respondenty. Výzkumný vzorek (n - 13, studenti tělesné výchovy, průměrný věk 23,6 let, 7 mužů a 6 žen) byl požádán, aby dotazník přečetl a posoudil relevanci a srozumitelnost, kulturní vhodnost jednotlivých položek a případně napsal k otázkám komentář. Připomínky byly zaneseny do dotazníku. Tak vznikla pracovní česká verze dotazníku.

4. krok: 1. zpětný překlad pracovní české verze dotazníku

Pracovní českou verzi přeložil zpět to angličtiny překladatel E. Přeložil však pouze 48 otázek obsažených v OMSAT-3*. Na základě doporučení autorů dotazníku jsme do zpětného překladu nezahrnuli všech 85 otázek OMSAT-3. Autoři totiž zbývajících 37 otázek vyřadili pro jejich nízkou faktorovou zátěž či formulační neobratnost.

5. krok: Posuzování shody 1. zpětného překladu pracovní české verze s originálem

Ekvivalenci zpětného překladu a originální verze posoudili další tři nezávislí odborníci (D, F a G). Srovnávali rozdíl v sémantickém významu vět jako celku, tak jejich sémantických jednotek. Z celkového počtu 48 otázek byl zpětný překlad označen za víceméně identický u 22 otázek (46\%), u 21 otázek (43\%) byly zaznamenány drobné významové rozdíly, u 5 otázek $(10,5 \%)$ byl zjištěn zásadnější významový rozdíl. Z celkového počtu sémantických jednotek (108) se 86 (79,7\%) shodovalo, u 14 byly nalezeny menší významové rozdíly (12,9 \%), u $8(7,4 \%)$ pak byly významové rozdíly větší.

6. krok: Přeformulování položek, jejich 2. zpětný překlad a vznik české verze OMSAT-3*

Otázky, u kterých byl objeven př́liš velký významový rozdíl, byly na základě doporučení překladatelů $\mathbf{D}, \mathbf{F}$ a $\mathbf{G}$ přeformulovány. Změny byly opět zaneseny do dotazníku. Po přeformulování neshodujících se položek provedl překladatel $\mathbf{H}$ zpětný překlad otázek, které byly v rámci předešlé retranslace označeny za neodpovídající. Celkem se jednalo o 24 otázek

7. krok: Posouzení shody české verze OMSAT-3* dotazníku s originálem

Posléze byla opětovně posouzena míra významové shody. Komise (D, F a G) konstatovala, že pouze 13 otázek ze 48 vykazovalo drobné sémantické rozdíly ( $27 \%$ ), a to vždy pouze v jedné sémantické jednotce (12\%).

Tab. 2: Design překladu znázorněný na vybraných otázkách

\begin{tabular}{|l|l|l|l|}
\hline $\begin{array}{l}\text { MENTÁLNÍ } \\
\text { DOVEDNOST }\end{array}$ & \multicolumn{1}{|c|}{ Stanovování cílů } & \multicolumn{1}{|c|}{$\begin{array}{c}\text { Opětovné zaměření } \\
\text { pozornosti }\end{array}$} & \multicolumn{1}{|c|}{ Reakce na stress } \\
\hline AJ originál & $\begin{array}{l}\text { I set goals to improve daily } \\
\text { aspects of my performance. }\end{array}$ & $\begin{array}{l}\text { Mistakes often lead to other } \\
\text { mistakes when I compete }\end{array}$ & $\begin{array}{l}\text { I experience performance } \\
\text { problems because I am too } \\
\text { nervous. }\end{array}$ \\
\hline Překladatel A & $\begin{array}{l}\text { Stanovuji si cíle, které } \\
\text { přispívají ke každodennímu } \\
\text { zlepšování mého výkonu. }\end{array}$ & $\begin{array}{l}\text { Neočekávané události } \\
\text { a chyby v průběhu soutěže } \\
\text { vedou k dalším chybám. }\end{array}$ & $\begin{array}{l}\text { Moje sportovní výkonnost je } \\
\text { nevyrovnaná, protože bývám } \\
\text { př́liš nervózní. }\end{array}$ \\
\hline Překladatel B & $\begin{array}{l}\text { Stanovuji si cíle k vylepšení } \\
\text { každodenních aspektů svého } \\
\text { výkonu. }\end{array}$ & $\begin{array}{l}\text { Když soutěžím, chyby } \\
\text { vyvolávají další chyby. }\end{array}$ & $\begin{array}{l}\text { Mám problémy s výkonem, } \\
\text { protože jsem pŕiliš nervózní. }\end{array}$ \\
\hline Překladatel C & $\begin{array}{l}\text { Stanovuji si cíle, aby denně } \\
\text { zlepšovaly mé výkony. }\end{array}$ & $\begin{array}{l}\text { Při soutěži často vedou mé } \\
\text { chyby k dalším chybám. }\end{array}$ & $\begin{array}{l}\text { Při závodění zažívám potíže, } \\
\text { protože jsem př́iliš nervózní. }\end{array}$ \\
\hline $\begin{array}{l}\text { Pracovní česká } \\
\text { verze }\end{array}$ & $\begin{array}{l}\text { Stanovuji si cíle tak, aby } \\
\text { prŕispívali ke každodennímu } \\
\text { zlepšování mého výkonu. }\end{array}$ & $\begin{array}{l}\text { Při soutěži vedou mé chyby } \\
\text { k dalším chybám. }\end{array}$ & $\begin{array}{l}\text { Mám problémy s výkoností, } \\
\text { protože jsem pŕíliš nervózní. }\end{array}$ \\
\hline $\begin{array}{l}\text { 1. zpětný } \\
\text { anglický překlad }\end{array}$ & $\begin{array}{l}\text { I set goals that contribute to } \\
\text { improving my performance } \\
\text { every day. }\end{array}$ & $\begin{array}{l}\text { During a competition my } \\
\text { mistakes lead to more } \\
\text { mistakes. }\end{array}$ & $\begin{array}{l}\text { I have problems with } \\
\text { performance because I am } \\
\text { too nervous. }\end{array}$ \\
\hline
\end{tabular}




\begin{tabular}{|l|l|l|l|}
\hline $\begin{array}{l}\text { Výsledná } \\
\text { ceská verze }\end{array}$ & $\begin{array}{l}\text { Stanovuji si cíle, které } \\
\text { přispívají ke zlepšování } \\
\text { běžných složek mého } \\
\text { sportovního výkonu. }\end{array}$ & $\begin{array}{l}\text { Při soutěži/zápase vedou } \\
\text { mé chyby často k dalším } \\
\text { chybám. }\end{array}$ & $\begin{array}{l}\text { Mívám problémy } \\
\text { s výkonností, protože jsem } \\
\text { př́liš nervózní. }\end{array}$ \\
\hline $\begin{array}{l}\text { 2. zpětný } \\
\text { anglický překlad }\end{array}$ & $\begin{array}{l}\text { I am convinced that despite } \\
\text { the obstacles I come across } \\
\text { I can succeed in my sport. }\end{array}$ & $\begin{array}{l}\text { During a match/ } \\
\text { competition, mistakes often } \\
\text { tend to lead to further } \\
\text { mistakes. }\end{array}$ & $\begin{array}{l}\text { I can have performance } \\
\text { issues because I am too } \\
\text { nervous. }\end{array}$ \\
\hline
\end{tabular}

\section{8. krok: Posouzení srozumitelnosti výsledné české verze}

Výsledná česká verze byla $\mathrm{v}$ rámci druhé pilotní studie rozšířena mezi pět osob za účelem posouzení srozumitelnosti otázek i instrukcí. Jednalo se o magisterské studenty Fakulty tělesné kultury Univerzity Palackého v Olomouci. Studenti poukazovali především na grafickou úpravu a tiskové chyby v dotazníku - překlepy, chybějící tečky, chybné odsazení či zarovnání. Tyto nedostatky byly odstraněny. Takto očištěná česká verze dotazníku OMSAT-3* byla nachystána $\mathrm{k}$ distribuci mezi sportovce za účelem potvrzení psychometrických vlastností dotazníku.

\section{DESIGN STANDARDIZACE}

Vyhodnocování reliability a obsahové validity české verze dotazníku jsme postupně provedli na třech různých populacích. Na základě analýzy dat a rozboru dílčích výsledků jsme totiž rozšiřovali a měnili strukturu souboru. Na posledním, třetím souboru jsme pak provedli analýzu pomocí metody hlavních komponent.

\section{Výzkumný soubor}

Základní charakteristiky výzkumných souborů, kterým jsme zadali českou verzi OMSAT-3*, shrnuje Tabulka 3. Respondenti byli rozděleni podle výkonnostní úrovně na základě stejného klíče jako kanadská populace.

Výběr 1. výzkumného souboru byl proveden účelovým výběrem v kombinaci s technikou sněhové koule. Z hlediska účelového výběru bylo hlavním kritériem, aby struktura vzorku přibližně odpovídala kanadskému originálu - tedy dělení na základě pohlaví, úrovně výkonnosti, barvitosti sportů a věku. Celkem byli respondenti vybráni z 16 sportů, přestože Durand-Bush, Salmela a Green-Demers (2001) konstatují, že dotazník je možné využít v rámci jakéhokoliv sportu, pro muže i ženy a již od žákovských kategorií, tedy mělo by se jednat o instrument široce využitelný. Mohli jsme tedy předpokládat, že př́padné rozdíly ve výzkumném souboru by se nemusely významněji promítnout do psychometrických hodnot.

Snowball technika byla využita za účelem teoretického naplnění vzorku pro potřebu překladu.

Vzhledem k tomu, že řada položek se ukázala jako problematická a reliabilita jako vnitřní konzistence byla dostatečná jen u části mentálních dovedností, rozhodli jsme se svůj výzkumný soubor rozšsiritit. 
Tab. 3: Popis jednotlivých výzkumných souborů

\begin{tabular}{|c|c|c|c|}
\hline SOUBOR & \multicolumn{2}{|c|}{$\begin{array}{l}\text { 1. výzkumný } \\
\text { soubor }\end{array}$} & \\
\hline ÚROVEN & Počet & Procento & \\
\hline $\begin{array}{l}\text { regionální } \\
\text { úroveň }\end{array}$ & 46 & 22,9 & \\
\hline $\begin{array}{l}\text { celostátní } \\
\text { úroveň }\end{array}$ & 109 & 54,2 & \\
\hline $\begin{array}{l}\text { národní } \\
\text { reprezentace }\end{array}$ & 46 & 22,9 & \\
\hline Celkem & 201 & 100 & \\
\hline POHLAVÍ & Počet & Procento & \\
\hline Muži & 128 & 63,7 & \\
\hline Ženy & 73 & 36,3 & \\
\hline Celkem & 201 & 100 & \\
\hline VĚK & Min & $\operatorname{Max}$ & Průměr \\
\hline Hodnota & 11 & 42 & 17,95 \\
\hline
\end{tabular}

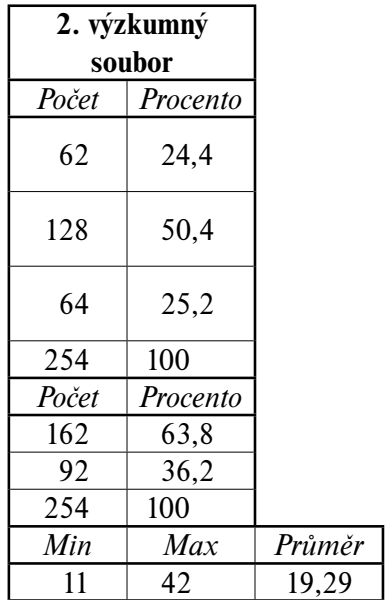

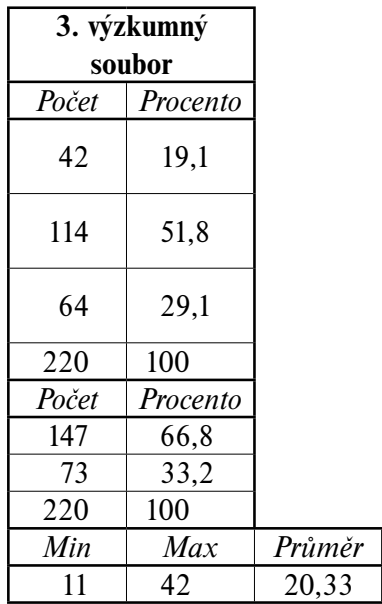

Poznámka. Počet = počet zahrnutých respondentů členěných dle jednotlivých kritérii; Procento = procentuální zastoupení daných respondentů z celkového počtu; $M i n$ = minimální věk respondentů v souboru; Max = maximální věk respondentů v souboru; Průměr = průměrný věk respondentů v souboru.

Druhý výzkumný soubor obsahoval všechny respondenty z 1. výzkumného souboru, ale byl obohacen o 53 nových probandů působících v kategorii dospělých a na vrcholové úrovni. Je tedy v průměru starší a sportovně zkušenější než 1 . výzkumný soubor. Celkem byli respondenti vybráni z 22 sportů.

Protože i Cronbachova alfa u některých škál zůstávala nadále nedostatečná, rozhodli jsme se vytvořit 3. výzkumný soubor, u kterého jsme předpokládali vyšší porozumění otázkám. Vznikl na základě 2. výzkumného souboru. Vyřadili jsme však všechny sportovce mladší 15 let. Tak jsme zajistili větší sportovní zkušenost i vyšší věkový průměr vzorku, tedy potenciálně i vyšši šanci porozumění některým pojmům cizojazyčného původu.

\section{ZPRACOVÁNÍ DAT}

Otázky jsme posuzovali z hlediska vzájemné korelace jednotlivých položek, které by měly tvořit škálu, a z hlediska vnitřní konzistence takovéto škály. Hodnoty Cronbachova koeficientu alfa vyšší než 0,7 jsou dle Klinea (1993) v psychologii dostačující. Jako položky nevhodné pro tvorbu škály dále považujeme ty položky (označeno *), které dosahují vzájemných korelací vyšších než 0,85 či nižších než 0,25 . Dalším vodítkem je pak počet chybějících hodnot. Chybějící hodnota může odkazovat na skutečnost, že respondenti otázce nerozuměli. Respondenti totiž dostali instrukce, aby nevyplňovali odpověd', pokud otázku nechápou. U 3. výběrového souboru jsme také provedli analýzu hlavních komponent.

Tak jsme identifikovali otázky či dimenze, které jsou oproti kanadskému originálu pravděpodobně nesrozumitelné či nevhodně formulované a u kterých bude potřeba zajistit jejich vyšší validitu - at již jinou formulací či dalšími postupy vedoucími k zajištování validity. 


\section{VÝSLEDKY}

Tabulka 4 ukazuje Cronbachovu alfu pro jednotlivé výběry i pro původní kanadský vzorek. Hvědičkou (*) označujeme hodnoty hraniční. Dvěma hvězdičkami (**) jsou uvedeny hodnoty, které jsou prríliš nízké (Cronbachova alfa <0,7).

Tab. 4: Koeficient Cronbachova alfa pro jednotlivé výběry a původní kanadské studie

\begin{tabular}{|l|l|l|l|c|}
\hline MENTÁLNÍ DOVEDNOST & $\begin{array}{c}\boldsymbol{\alpha} \\
\text { 1.výzkumný } \\
\text { soubor }\end{array}$ & $\begin{array}{c}\boldsymbol{\alpha} \\
\text { 2.výzkumný } \\
\text { soubor }\end{array}$ & $\begin{array}{c}\boldsymbol{\alpha} \\
\text { 3.výzkumný } \\
\text { soubor }\end{array}$ & $\begin{array}{c}\boldsymbol{\alpha} \\
\text { Originál }\end{array}$ \\
\hline Stanovování cílů & 0,76 & 0,75 & 0,77 & 0,74 \\
\hline Sebedi̊věra & 0,77 & 0,75 & 0,75 & 0,78 \\
\hline Odhodlání & 0,84 & 0,82 & 0,83 & 0,79 \\
\hline Reakce na stres & $0,53^{* *}$ & $0,68^{*}$ & 0,70 & 0,73 \\
\hline Relaxace & $0,61^{* *}$ & $0,62^{* *}$ & $0,62^{* *}$ & 0,83 \\
\hline Zvládání strachu & $0,48^{* *}$ & $0,68^{*}$ & $0,69^{*}$ & $0,68^{*}$ \\
\hline Aktivace & 0,72 & 0,70 & $0,69^{*}$ & 0,79 \\
\hline Zaměření pozornosti & $0,70^{*}$ & 0,79 & 0,77 & 0,72 \\
\hline Imaginace & $0,63^{* *}$ & $0,65^{* *}$ & $0,65^{* *}$ & 0,88 \\
\hline Plánování soutěže & 0,72 & 0,74 & 0,76 & 0,83 \\
\hline Mentální trénink & 0,75 & 0,76 & 0,76 & 0,76 \\
\hline Opětovné zaměření pozornosti & $0,65^{* *}$ & $0,60^{* *}$ & $0,57^{* *}$ & 0,81 \\
\hline
\end{tabular}

Poznámka. $\boldsymbol{\alpha}=$ hodnota Cronbachovy alfy pro jednotlivé soubory; $\boldsymbol{\alpha}$ Originál = hodnota Cronbachovy alfy pro kanadský výzkumný soubor (Durand-Bush, Salmela \& Green-Demers; 2001); * = hraniční hodnota Cronbachovy alfa škály; ** = prŕliš nízká hodnota Cronbachovy alfa škály.

Tabulka 5 ukazuje vzájemné korelace otázek obsažených u jednotlivých škál na př́kladu škály imaginace. Nevhodné položky označujeme opět *. Položka I4 („Při představování dokážu pocitovat pochyby") vykazuje př́liš nízkou korelaci s ostatními položkami. Odůvodněním může být, že znění otázky odkazuje nejen na imaginaci, ale i na situaci, kdy se setkáme s cizí osobou a představíme se.

Tab. 5: Korelační matice položek škály „imaginace“ (1. výzkumný soubor)

\begin{tabular}{|c|c|c|c|c|c|}
\hline & I1 & I2 & I3 & I4 & a při vyrazení položky \\
\hline I1 & 1,00 & 0,36 & 0,40 & 0,21 & 0,53 \\
\hline I2 & 0,36 & 1,00 & 0,40 & 0,09 & 0,58 \\
\hline I3 & 0,40 & 0,40 & 1,00 & 0,32 & 0,46 \\
\hline I4 & $0,21^{*}$ & $0,09^{*}$ & 0,32 & 1,00 & 0,65 \\
\hline
\end{tabular}

Poznámka. I1, I2,I3, I4 = pořadí otázky posuzující imaginaci; $\alpha$ při vyřazení položky = změna v hodnotě Cronbachovy alfy, pokud by položka byla $z$ dotazníku vyřazena, * = př́liš nízká či vysoká hodnota korelace položky s ostatními položkami.

Tabulka 6 uvádí počet chybějících hodnot u jednotlivých položek, a to na příkladu nejširšího 2 . výzkumného souboru. 
Tab. 6: Počet chybějících odpovědí u jednotlivých položek a počet komentářů respondentů, kteří otázce neporozuměli, u 2. výzkumného souboru

\begin{tabular}{|c|c|c|c|}
\hline Mentální dovednost & Č.o. & Zn. & $\begin{array}{l}\text { Chybějící } \\
\text { hodnoty }\end{array}$ \\
\hline \multirow{4}{*}{ Stanovování cílů } & 1 & $\mathrm{SC} 1$ & 4 \\
\hline & 10 & $\mathrm{SC} 2$ & 4 \\
\hline & 23 & $\mathrm{SC} 3$ & 4 \\
\hline & 41 & $\mathrm{SC} 4$ & 3 \\
\hline \multirow{4}{*}{ Sebedůvěra } & 2 & SB1 & 3 \\
\hline & 12 & SB2 & 3 \\
\hline & 28 & SB3 & 2 \\
\hline & 48 & SB4 & 2 \\
\hline \multirow{4}{*}{ Odhodlání } & 7 & $\mathrm{O} 1$ & 4 \\
\hline & 17 & $\mathrm{O} 2$ & 3 \\
\hline & 30 & $\mathrm{O} 3$ & 3 \\
\hline & 39 & $\mathrm{O} 4$ & 2 \\
\hline \multirow{4}{*}{ Reakce na stres } & 6 & RS1 & 2 \\
\hline & 14 & RS2 & 4 \\
\hline & 32 & RS3 & 3 \\
\hline & 36 & RS4 & 2 \\
\hline \multirow{4}{*}{ Relaxace } & 3 & $\mathrm{R} 1$ & 3 \\
\hline & 19 & $\mathrm{R} 2$ & 5 \\
\hline & 29 & R3 & 2 \\
\hline & 42 & $\mathrm{R} 4$ & 2 \\
\hline \multirow{4}{*}{ Zvládání strachu } & 4 & ZS1 & 5 \\
\hline & 16 & ZS2 & 2 \\
\hline & 24 & ZS3 & $6^{*}$ \\
\hline & 43 & ZS4 & 4 \\
\hline
\end{tabular}

\begin{tabular}{|c|c|c|c|}
\hline Mentální dovednost & Č.o. & Zn. & $\begin{array}{l}\text { Chybějíí } \\
\text { hodnoty }\end{array}$ \\
\hline \multirow{4}{*}{ Aktivace } & 5 & A1 & 2 \\
\hline & 20 & $\mathrm{~A} 2$ & 4 \\
\hline & 37 & A3 & 3 \\
\hline & 46 & $\mathrm{~A} 4$ & 5 \\
\hline \multirow{4}{*}{ Zaměření pozornosti } & 8 & ZP1 & 4 \\
\hline & 15 & ZP2 & 4 \\
\hline & 31 & ZP3 & 2 \\
\hline & 38 & ZP4 & 3 \\
\hline \multirow{4}{*}{ Imaginace } & 9 & $\mathrm{I} 1$ & $10 *$ \\
\hline & 18 & $\mathrm{I} 2$ & $7 *$ \\
\hline & 26 & $\mathrm{I} 3$ & $10 *$ \\
\hline & 33 & I4 & $11 *$ \\
\hline \multirow{4}{*}{ Plánování soutěže } & 11 & PS1 & 3 \\
\hline & 25 & PS2 & $10 *$ \\
\hline & 40 & PS3 & 3 \\
\hline & 47 & PS4 & 3 \\
\hline \multirow{4}{*}{ Mentální trénink } & 13 & MT1 & $8 *$ \\
\hline & 21 & MT2 & $6^{*}$ \\
\hline & 35 & MT3 & 7* \\
\hline & 45 & MT4 & $8 *$ \\
\hline \multirow{4}{*}{$\begin{array}{l}\text { Opětovné zaměření } \\
\text { pozornosti }\end{array}$} & 22 & OP1 & 5 \\
\hline & 27 & OP2 & 2 \\
\hline & 34 & OP3 & 6 \\
\hline & 44 & OP4 & 2 \\
\hline
\end{tabular}

Poznámka. Č.o. = číslo otázky v dotazníku; Zn. = označení položky při statistickém zpracování dat; Chybějicí hodnoty $=$ počet neuvedených odpovědí na danou otázku respondenty; * = vysoký počet chybějících hodnot.

Tabulka 7 znázorn̆uje na př́kladu 3. výzkumného souboru procento rozptylu ve 12 faktorech, jejich počet odpovídá kanadskému originálu. 3. výzkumný soubor byl zvolen proto, že ve srovnání s ostatními soubory vykazuje jak nejvyšší hodnoty Cronbachova alfa, tak kvůli tomu, že 12 faktorů pokrývá nejvyšší procento rozptylu $(64,74 \%)$. 
Tab. 7: Vlastní číla a procento vysvětleného rozptylu 3. výzkumného souboru

\begin{tabular}{|c|c|c|c|c|}
\hline $\begin{array}{c}\text { Pořadí } \\
\text { faktoru }\end{array}$ & $\begin{array}{c}\text { Vlastní } \\
\text { číslo }\end{array}$ & $\begin{array}{c}\text { Procento } \\
\text { celkového rozptylu }\end{array}$ & $\begin{array}{c}\text { Kumulativní hodnota } \\
\text { vlastních čísel }\end{array}$ & $\begin{array}{c}\text { Kumulativní procentuální } \\
\text { hodnota rozptylu }\end{array}$ \\
\hline 1 & 7,73 & 16,11 & 7,73 & 16,11 \\
\hline 2 & 6,90 & 14,37 & 14,63 & 30,48 \\
\hline 3 & 2,72 & 5,67 & 17,35 & 36,15 \\
\hline 4 & 2,40 & 5,00 & 19,75 & 41,15 \\
\hline 5 & 1,97 & 4,10 & 21,72 & 45,25 \\
\hline 6 & 1,66 & 3,46 & 23,38 & 48,71 \\
\hline 7 & 1,48 & 3,09 & 24,87 & 51,80 \\
\hline 8 & 1,42 & 2,95 & 26,28 & 54,76 \\
\hline 9 & 1,31 & 2,73 & 27,59 & 57,49 \\
\hline 10 & 1,23 & 2,56 & 28,82 & 60,05 \\
\hline 11 & 1,17 & 2,44 & 30,00 & 62,49 \\
\hline 12 & 1,08 & 2,25 & 31,07 & 64,74 \\
\hline
\end{tabular}

Tabulka 8 dokumentuje faktorové zátěže ze stejného souboru. Označené * jsou hodnoty, které vykazují dostatečnou faktorovou zátěž (vy̌ší než 0,5). Přijatelné hodnoty jsou u mentálních dovedností odhodlání, plánování soutěže a zaměrení pozornosti. Hraniční hodnoty jsou pak u položek sebedůvěry, mentálního tréninku, reakce na stres, zvládání strachu a stanovování cílư, když některé z otázek vykazují zátěže nižší než 0,5 (ale všechny jsou vyšší než 0,39).

Tab. 8: Faktorové zátěže položek na 3. výzkumném souboru

\begin{tabular}{|c|c|c|c|c|c|c|c|c|c|c|c|c|c|c|}
\hline $\begin{array}{c}\text { Mentální } \\
\text { dovednost }\end{array}$ & č.o. & Zn. & \begin{tabular}{|c} 
Faktor \\
1 \\
\end{tabular} & \begin{tabular}{|c|} 
Faktor \\
2 \\
\end{tabular} & $\begin{array}{c}\text { Faktor } \\
3 \\
\end{array}$ & $\begin{array}{c}\text { Faktor } \\
4 \\
\end{array}$ & $\begin{array}{c}\text { Faktor } \\
5 \\
\end{array}$ & $\begin{array}{c}\text { Faktor } \\
6 \\
\end{array}$ & \begin{tabular}{|c} 
Faktor \\
7 \\
\end{tabular} & \begin{tabular}{|c} 
Faktor \\
8 \\
\end{tabular} & \begin{tabular}{|c} 
Faktor \\
9 \\
\end{tabular} & $\begin{array}{c}\text { Faktor } \\
10 \\
\end{array}$ & $\begin{array}{c}\text { Faktor } \\
11 \\
\end{array}$ & $\begin{array}{c}\text { Faktor } \\
12 \\
\end{array}$ \\
\hline \multirow{4}{*}{$\begin{array}{l}\text { Stanovování } \\
\text { cílů }\end{array}$} & 1 & SC1 & 0,17 & $-0,08$ & 0,10 & $-0,22$ & 0,43 & $-0,08$ & 0,04 & $-0,04$ & 0,04 & 0,38 & 0,18 & 0,26 \\
\hline & 10 & SC2 & 0,06 & $-0,02$ & 0,20 & $-0,09$ & 0,22 & $-0,07$ & $-0,09$ & 0,12 & 0,09 & $0,69^{*}$ & $-0,03$ & 0,16 \\
\hline & 23 & SC3 & 0,14 & 0,03 & 0,26 & 0,02 & 0,19 & 0,09 & 0,03 & 0,05 & 0,04 & $0,71^{*}$ & 0,21 & $-0,02$ \\
\hline & 41 & SC4 & 0,28 & $-0,09$ & 0,16 & $-0,21$ & 0,35 & $-0,06$ & 0,17 & 0,31 & 0,07 & 0,39 & 0,18 & 0,06 \\
\hline \multirow{4}{*}{ Sebedůvěra } & 2 & SB1 & $-0,06$ & $-0,04$ & $0,51^{*}$ & $-0,04$ & 0,39 & 0,07 & $-0,05$ & 0,39 & 0,06 & 0,19 & $-0,02$ & 0,19 \\
\hline & 12 & SB2 & 0,02 & $-0,07$ & $0,77^{*}$ & 0,13 & 0,15 & 0,09 & 0,01 & $-0,01$ & 0,01 & 0,14 & 0,09 & 0,16 \\
\hline & 28 & SB3 & $-0,09$ & 0,05 & 0,39 & $-0,16$ & 0,16 & 0,22 & $-0,08$ & $0,57^{*}$ & 0,21 & 0,20 & $-0,08$ & $-0,03$ \\
\hline & 48 & SB4 & 0,21 & 0,12 & $0,75^{*}$ & 0,03 & 0,12 & 0,00 & 0,08 & 0,18 & 0,01 & 0,01 & $-0,07$ & 0,17 \\
\hline \multirow{4}{*}{ Odhodlání } & 7 & 01 & 0,03 & 0,01 & 0,07 & 0,18 & $0,67^{*}$ & 0,03 & $-0,03$ & 0,13 & 0,14 & 0,16 & 0,15 & 0,03 \\
\hline & 17 & $\mathrm{O} 2$ & 0,12 & $-0,09$ & 0,30 & 0,02 & $0,60^{*}$ & $-0,04$ & 0,12 & 0,22 & $-0,01$ & 0,21 & 0,25 & $-0,01$ \\
\hline & 30 & $\mathrm{O} 3$ & 0,16 & $-0,01$ & 0,10 & $-0,11$ & $0,83^{*}$ & 0,03 & 0,07 & 0,00 & $-0,01$ & 0,09 & 0,09 & 0,05 \\
\hline & 39 & $\mathrm{O} 4$ & 0,16 & $-0,03$ & 0,00 & 0,03 & $0,83^{*}$ & 0,04 & $-0,04$ & $-0,09$ & $-0,05$ & 0,01 & 0,04 & 0,02 \\
\hline \multirow{4}{*}{$\begin{array}{c}\text { Reakce na } \\
\text { stres }\end{array}$} & 6 & RS1 & 0,02 & $0,63^{*}$ & 0,04 & $-0,10$ & 0,10 & 0,19 & 0,02 & $-0,05$ & 0,21 & $-0,25$ & $-0,08$ & $-0,12$ \\
\hline & 14 & RS2 & $-0,02$ & $0,75^{\star}$ & 0,14 & $-0,07$ & $-0,01$ & 0,05 & $-0,13$ & 0,01 & 0,01 & $-0,13$ & $-0,04$ & 0,07 \\
\hline & 32 & RS3 & 0,10 & $0,7^{*}$ & $-0,05$ & 0,08 & 0,04 & 0,03 & $-0,11$ & $-0,02$ & 0,17 & $-0,02$ & $-0,12$ & 0,06 \\
\hline & 36 & RS4 & $-0,08$ & 0,47 & $-0,11$ & $-0,02$ & $-0,03$ & $-0,13$ & 0,25 & 0,11 & $0,6^{*}$ & $-0,11$ & 0,16 & $-0,05$ \\
\hline \multirow{4}{*}{ Relaxace } & 3 & R1 & $-0,09$ & $-0,08$ & 0,06 & $0,81^{*}$ & 0,10 & 0,06 & 0,04 & $-0,07$ & 0,04 & $-0,16$ & $-0,02$ & 0,05 \\
\hline & 19 & R2 & 0,07 & 0,19 & 0,15 & 0,18 & 0,02 & 0,03 & 0,04 & $-0,02$ & 0,08 & 0,04 & 0,06 & $0,76^{*}$ \\
\hline & 29 & R3 & 0,01 & $-0,02$ & 0,08 & $0,83^{*}$ & $-0,07$ & 0,03 & 0,00 & 0,03 & 0,02 & 0,04 & 0,05 & 0,07 \\
\hline & 42 & R4 & 0,13 & 0,12 & 0,20 & 0,44 & $-0,04$ & 0,04 & $-0,06$ & $-0,09$ & 0,07 & 0,23 & 0,26 & 0,42 \\
\hline
\end{tabular}




\begin{tabular}{|c|c|c|c|c|c|c|c|c|c|c|c|c|c|c|}
\hline \multirow{4}{*}{$\begin{array}{l}\text { Zvládání } \\
\text { strachu }\end{array}$} & 4 & S1 & 0,16 & 0,40 & $-0,08$ & 0,38 & $-0,15$ & 0,04 & $-0,04$ & 0,47 & $-0,21$ & 0,12 & 0,08 & $-0,05$ \\
\hline & 6 & S2 & $-0,06$ & $0,8^{*}$ & ד & 0,06 & 004 & 0,03 & ת20 & 028 & ] & 0,07 & 0,02 & מ \\
\hline & 24 & S3 & $-0,06$ & $0,58^{*}$ & $-0,08$ & 0,04 & 0,08 & $-0,07$ & 0,02 & 0,13 & 0,05 & 0,32 & 0,12 & $\overline{0,01}$ \\
\hline & 3 & S4 & 0,00 & $0,67^{*}$ & $-0,20$ & 0,12 & 0,11 & 0,08 & 0,10 & 0,06 & 0,11 & 0,09 & 0,01 & 0,01 \\
\hline \multirow{4}{*}{ Aktivace } & 3 & 1 & 0,21 & 0,02 & 0,26 & 0,12 & 0,05 & 0,17 & $-0,13$ & $-0,06$ & $0,59^{*}$ & 0,22 & $-0,10$ & 0,1 \\
\hline & 20 & A2 & 0,14 & $-0,13$ & 0,09 & 0,02 & 0,01 & 0,26 & $-0,24$ & 0,17 & $0,53^{*}$ & 0,15 & $-0,03$ & 0,03 \\
\hline & 37 & 3 & 0,01 & $-0,05$ & $0,70^{*}$ & 0,06 & $-0,03$ & 0,17 & $-0,18$ & $-0,11$ & 0,12 & 0,19 & 0,21 & $-0,16$ \\
\hline & 6 & 4 & 0,26 & $-0,07$ & 0,38 & 0,05 & $-0,05$ & $-0,21$ & 0,03 & $-0,08$ & 0,46 & 0,07 & 0,29 & 0,22 \\
\hline \multirow{4}{*}{$\begin{array}{l}\text { Zaměření } \\
\text { pozornosti }\end{array}$} & 8 & $\mathrm{P} 1$ & $-0,02$ & $0,8^{*}$ & $-0,04$ & $-0,07$ & $-0,06$ & $-0,15$ & 0,00 & 0,10 & 0,04 & $-0,04$ & $-0,03$ & 0,2 \\
\hline & 15 & ZP2 & 0,03 & $0,72^{*}$ & 0,06 & 0,02 & $-0,01$ & $-0,05$ & $-0,04$ & 0,05 & $-0,18$ & $-0,04$ & 0,00 & $-0,12$ \\
\hline & 31 & ZP3 & $-0,07$ & $0,60^{*}$ & 0,03 & $-0,01$ & 0,01 & 0,13 & 0,30 & $-0,24$ & $-0,06$ & 0,15 & $-0,18$ & 0,09 \\
\hline & 8 & $\mathrm{P} 4$ & $-0,04$ & $0,75^{*}$ & 0,04 & $-0,11$ & $-0,11$ & 0,05 & 0,19 & $-0,07$ & $-0,04$ & 0,15 & $-0,12$ & 0,0 \\
\hline \multirow{4}{*}{ Imaginace } & $y$ & $\pi$ & 0,16 & $-0,03$ & 0,05 & 0,01 & 0,23 & $0,53^{*}$ & 0,00 & 0,02 & $-0,09$ & 0,19 & 0,10 & $0,53^{*}$ \\
\hline & 18 & 12 & $-0,05$ & 0,07 & 0,16 & 0,10 & $-0,01$ & $0,81^{*}$ & 0,04 & 0,06 & 0,06 & $-0,05$ & 0,21 & 0,07 \\
\hline & 26 & 13 & 0,30 & 0,04 & 0,15 & $-0,07$ & 0,11 & 0,36 & $-0,00$ & 0,3 & 0,05 & 0,03 & 0,25 & 0,48 \\
\hline & 33 & 14 & 0,15 & 0,34 & 0,05 & $-0,29$ & 0,16 & 0,13 & $-0,26$ & $-0,16$ & 0,12 & $-0,19$ & 0,30 & 0,38 \\
\hline \multirow{4}{*}{$\begin{array}{l}\text { Plánování } \\
\text { soutěže }\end{array}$} & 11 & 51 & $0,63^{*}$ & 0,03 & 0,00 & $-0,01$ & 0,10 & $-0,25$ & 0,07 & 0,16 & $-0,11$ & 0,13 & 0,16 & $\overline{0,1}$ \\
\hline & 25 & PS2 & $0,78^{*}$ & $-0,04$ & 0,06 & $-0,08$ & 0,11 & 0,03 & 0,00 & 0,01 & 0,03 & 0,07 & 0,16 & 0,0 \\
\hline & 40 & PS3 & $0,72^{*}$ & 0,00 & 0,08 & 0,03 & 0,25 & 0,00 & 0,10 & $-0,14$ & 0,01 & 0,03 & 0,15 & 0,07 \\
\hline & 47 & S4 & $0,66^{*}$ & $-0,06$ & 0,0 & 0,05 & 0 , & 0,14 & $-0,0$ & 0,0 & 0 & 0,0 & $-0,1$ &, 0 \\
\hline \multirow{4}{*}{$\begin{array}{c}\text { Mentální } \\
\text { trénink }\end{array}$} & 13 & MT1 & 0,30 & 0,01 & 0,22 & $-0,03$ & 0,30 & 0,13 & $-0,04$ & $-0,05$ & 0,01 & $-0,10$ & $0,67^{*}$ & $\overline{0,08}$ \\
\hline & 21 & ит2 & 0,07 & $-0,11$ & $-0,02$ & 0,09 & 0,14 & 0,21 & 0,08 & 0,09 & 0,03 & 0,22 & $0,73^{*}$ & 0,14 \\
\hline & 35 & MT3 & 0,31 & $-0,10$ & 0,14 & 0,09 & 0,24 & 0,09 & $-0,06$ & $-0,32$ & $-0,07$ & 0,24 & 0,49 & 0,0 \\
\hline & 45 & MT4 & 0,49 & $-0,18$ & 0,07 & $-0,06$ & 0,18 & 0,03 & 0,09 & 0,17 & 0,17 & 0,07 & 0,41 & 0,03 \\
\hline \multirow{4}{*}{$\begin{array}{l}\text { Opětovné } \\
\text { zaměření } \\
\text { pozornosti }\end{array}$} & $\angle L$ & $\mathrm{P} 1$ & 0,05 & 0,32 & 0,01 & 0,06 & 0,07 & $-0,11$ & $0,76^{*}$ & 0,05 & 0,08 & $-0,12$ & 0,07 & 0,09 \\
\hline & 27 & OP2 & $-0,09$ & $0,8^{*}$ & 0,08 & $-0,07$ & $-0,10$ & $-0,01$ & 0,19 & $-0,01$ & 0,08 & $-0,08$ & 0,12 & 0,01 \\
\hline & 34 & OP3 & 0,03 & $0,7^{*}$ & $-0,07$ & 0,10 & $-0,01$ & 0,01 & 0,20 & $-0,22$ & $-0,11$ & $-0,06$ & 0,13 & 0,02 \\
\hline & 44 & OP4 & 0,10 & $-0,17$ & $-0,09$ & \begin{tabular}{|c|}
$-0,02$ \\
\end{tabular} & 0,02 & 0,22 & $0,67^{*}$ & $-0,13$ & $-0,14$ & 0,13 & $-0,03$ & $-0,13$ \\
\hline
\end{tabular}

Poznámka. Č.o. = číslo otázky v dotazníku; $Z n$. = označení položky při statistickém zpracování dat; * = hodnoty faktorové zátěže vyšší než 0,5 .

Ze statistické analýzy dat a opětovného rozboru problematických položek vyplynulo, že překlady některých otázek nejsou pro tuzemskou veřejnost adekvátní. To zahrnuje následující položky:

1. Položky, u kterých se hojně vyskytovaly chybějící hodnoty. Chybějící hodnoty tedy zčásti poukazují na nesrozumitelné otázky.

2. Položky, které nevykazovaly dostatečné psychometrické vlastnosti a nebyly vhodné pro tvorbu škál.

3. Položky, které společně nevytváŕí škálu.

4. Položky s nízkou faktorovou zátěží vzhledem k př́islušnému faktoru.

Domníváme se, že přinejmenším drobné úpravy ve formulaci bude potřeba učinit u 10 položek (Tabulka 9). Současně u škál odkazujících na mentální trénink, plánování soutěže a zvládání strachu se jeví jako vhodné uvést před otázkami definici mentální dovednosti, protože je zde vysoké procento chybějících odpovědí i komentářủ respondentů, že nerozumí otázce. 
Tab. 9: Otázky vhodné k reformulaci

\begin{tabular}{|c|c|c|c|}
\hline С̆.o. & Mentální dovednost & Česká verze OMSAT-3* & AJ originál \\
\hline 14 & Reakce na stres & $\begin{array}{l}\text { Při soutěži/zápase mé tělo zbytečně } \\
\text { ztuhne. }\end{array}$ & $\begin{array}{l}\text { My body tightens nnecessarily in } \\
\text { competition }\end{array}$ \\
\hline 3 & Relaxace & Je pro mne snadné rychle relaxovat. & I find it easy to relax quickly. \\
\hline 29 & Relaxace & $\begin{array}{l}\text { Umím účinně relaxovat během } \\
\text { kritických momentů při soutěži/ } \\
\text { zápasu. }\end{array}$ & $\begin{array}{l}\text { I can relax effectively during } \\
\text { critical moments in a competition. }\end{array}$ \\
\hline 42 & Relaxace & Je pro mne snadné relaxovat. & I find it easy to relax. \\
\hline 9 & Imaginace & $\begin{array}{l}\text { Snadno si v mysli vytvárím } \\
\text { mentální obrazy. }\end{array}$ & I have clear mental images. \\
\hline 33 & Imaginace & $\begin{array}{l}\text { Při představování dokážu pocitovat } \\
\text { pohyby. }\end{array}$ & $\begin{array}{l}\text { I find it easy to create mental } \\
\text { images. }\end{array}$ \\
\hline 18 & Imaginace & $\begin{array}{l}\text { Je pro mne snadné měnit mentální } \\
\text { obrazy ve své mysli. }\end{array}$ & $\begin{array}{l}\text { I find it easy to change images in } \\
\text { my mind. }\end{array}$ \\
\hline 26 & Imaginace & Mám jasné mentální obrazy. & $\begin{array}{l}\text { I can feel movements in my } \\
\text { imagery. }\end{array}$ \\
\hline 44 & $\begin{array}{l}\text { Opětovné zaměření } \\
\text { pozornosti }\end{array}$ & $\begin{array}{l}\text { Během tréninku přemítám nad } \\
\text { svými chybami. }\end{array}$ & $\begin{array}{l}\text { I dwell upon mistakes during } \\
\text { training. }\end{array}$ \\
\hline 4 & Zvládání strachu & $\begin{array}{l}\text { V mém sportu se vyskytuje řada } \\
\text { věcí, které jsou pro mne ohrožující } \\
\text { a ze kterých mám strach. }\end{array}$ & $\begin{array}{l}\text { There are a number of things in my } \\
\text { sport that are potentially dangerous } \\
\text { and make me afraid. }\end{array}$ \\
\hline
\end{tabular}

Poznámka. Č.o. = číslo otázky v dotazníku.

\section{DISKUSE}

Hlavním výzkumným cílem bylo přeložit a zahájit standardizaci Ottawského dotazníku mentálních dovedností ve sportu-3* (Ottawa Mental Skill Assessment Tool-3*, OMSAT-3*, Durand-Bush \& Salmela, 2001)

Výsledná česká verze OMSAT-3* byla vytvořena na základě kombinace opakovaného překladu do češtiny a zpětného překladu do angličtiny, posuzování sémantické přesnosti překladovými komisemi a pilotních studií. Shoda s kanadským originálem vyjádřená sémantickými jednotkami identifikovala pouze drobné sémantické rozdíly celkově u 13 otázek ze 48 (27\%), a to vždy pouze $\mathrm{v}$ jedné sémantické jednotce $\mathrm{z}$ celkového počtu 108 (12\%). To nepř́imo poukazuje na vysokou obsahovou validitu překladu.

Na základě administrace dotazníku postupně třem výzkumným souborům je však zřejmé, že dotazník v současné podobě není dostatečně kvalitním psychodiagnostickým nástrojem. U 1 . výzkumného souboru vykázalo uspokojivou reliabilitu jako vnitřní konzistenci pouze 7 z 12 mentálních dovedností (sebeduvěra, stanovování cílù, odhodlání, aktivace, zaměrení pozornosti, plánování soutěže a mentální trénink). I výsledky rozšîreného 2 . výzkumného souboru, který již svou strukturou více odpovídal kanadské populaci, potvrdily reliabilitu škál jako vnitřní konzistenci pouze u 7 ze 12 škál. Došlo však k jejímu nárůstu u škál reakce na stres a zvládání strachu. Proto jsme se rozhodli z 2. výzkumného souboru vytvořit 3. výzkumný soubor (n - 220), do kterého jsme zahrnuli pouze respondenty starší 15 let. Ve srovnání s kanadským souborem byl sice méně zkušený, ale starší (+0,73 let). Potvrdila se reliabilita jako vnitřní konzistence u 7 ze 12 škál. Mentální dovednost reakce na stres nahradila škálu aktivace, která stejně jako zvládání strachu vykazovala hraniční hodnotu. Možným odůvodněním toho, proč škály reakce na stres a zvládání strachu byly 
u staršího vzorku víc reliabilní, je, že starší sportovci mohou mít s prožíváním strachu a stresu ve svém sportu více zkušeností (Dias, Cruz, \& Fonseca, 2010). Závěry z posuzování vnitřní konzistence škál na 3. výzkumném souboru potvrdila i analýza hlavních komponent.

Z celkového pohledu je však třeba českou verzi dotazníku OMSAT-3* odmítnout jako neadekvátní kanadskému originálu. Domníváme se, že přes zdánlivou sémantickou přesnost české verze se významné rozdíly objevily proto, že se nám nepodařilo dostatečně zohlednit odlišnosti českého a kanadského sociokulturního kontextu, což snižuje obsahovou validitu. Řada respondentů nerozuměla některým tvrzením uvedeným v dotazníku, respektive pochopila je nesprávně. To je potvrzeno vysokým počtem chybějících hodnot (především u škál imaginace a mentálního tréninku) i množstvím komentářů respondentů. Zdůvodňujeme to v následujících bodech:

1. Psychologie sportu je v České republice sice oborem, který se vyučuje na řadě sportovních a pedagogických fakult, přesto však není u nás přiliš rozšířen. $Z$ toho vyplývá, že sportovně-psychologická terminologie nemusí být u české populace obecně známá, a termíny jsou pro mnohé sportovce nesrozumitelné. U sportovců se dlouhodobě upřednostňuje trénink motorických dovedností a rozvoj fyziologických charakteristik.

2. Velká většina využívaných psychodiagnostických metod v republice byla navržena původně pro jiné oblasti a až později byly některé $\mathrm{z}$ nich adaptovány pro oblast psychologie sportu. V současnosti existuje jen omezený počet specializovaných, sportovně-psychologických nástrojů (přehled ve Vičar, 2016). Oproti tomu ve světě byly vytvořeny desítky standardizovaných nástrojủ. Z toho může potenciálně vyplývat menší zkušenost místní sportovní komunity jak s testováním, tak i se sportovně-psychologickými výrazy.

3. Přestože sportovci a trenéři mnohdy zdůrazňují důležitost práce na psychice sportovce, samotná psychická příprava bývá spojována obyčejně až s vrcholovým sportem na národní či mezinárodní úrovni (Hřebičková, 2015). To může souviset s nižší zkušeností respondentů s terminologií.

4. V českém jazyce sice existují díla a publikace z oblasti psychologie sportu, obvykle se však jedná o sice obsáhlé, avšak spiše souhrnné učebnice (např. Psychologie sportu, Slepička, Hošek, \& Hátlová, 2009), které z velké části uplatňují poznatky z obecné psychologie na oblast sportu. Existuje pouze minimum přeložených zahraničních textů (např. Psychologie sportu, Tod, Thatcherová, \& Rahmanová, 2012). Z tohoto důvodu není v mnoha případech ustálena česká sportovně-psychologická terminologie, což může mít za následek, že samotní sportovci těmto termínům nerozumějí.

5. Pronikání př́slušné terminologie a poznatků do České republiky zabraňovalo rozdělení světa na dva geopolitické bloky - západní a východní. Výzkum ve východních zemích, kam jsme v minulosti patřili, se zabýval především tématy spojenými s vưlí, motivací a špičkovou výkonností. Západní badatelé se naopak mnohem více věnovali psychice sportovce, jeho osobnosti a prožívání ve spojení s aktuálním výkonem (Blahutková \& Pacholík, 2006). Sdílení západních poznatků dodnes mnohdy brzdí i jazyková bariéra - jak badatelů, tak samotných sportovců a trenérů. Téma mentálních dovedností je proto v České republice stále vnímáno jako relativně nové. Z toho pramení nízká obeznámenost zúčastněných $\mathrm{s}$ tématy, která jsou s mentálními dovednostmi spojena - včetně formulací otázek v dotazníku OMSAT-3*. Je sice nasnadě domnívat se, že čeští sportovci mnohdy intuitivně mentální dovednosti využívají, na druhou stranu to však nemusí nutně znamenat, že si dokážou tuto svou praktickou zkušenost propojit s teoretickými pojmy.

Pohlédněme nyní na získané výsledky z hlediska základního členění mentálních dovedností na tři skupiny - základní, psychosomatické a kognitivní. Všechny škály řazené do základních dovedností vykazovaly dostatečnou reliabilitu jako vnitřní konzistenci, prričemž respondenti zde takřka 
neuváděli, že by položkám nerozuměli. To může potvrzovat Orlickův (1992) předpoklad, že právě tyto dovednosti jsou lidem dobře známé, i proto, že jsou základními kameny pro rozvoj těch ostatních. Témata jako stanovování cílů, sebedůvěra či motivace jsou v České republice a bývalém východním bloku populární. Z psychosomatických dovedností se naopak reliabilita nepotvrdila vždy u $75 \%$, tedy u 3 ze 4 škál (reakce na stres, zvládání strachu a relaxace v př́padě 2. výzkumného souboru; zvládání strachu, relaxace a aktivace v př́ípadě 3 . výzkumného souboru). To může poukazovat zase na to, že aktuální prožívání sportovce je tématem historicky více diskutovaným západním proudem psychologie sportu. U kognitivních vlastností byla Cronbachova alfa dostatečná u 3 z 5 škál (mentální trénink, plánování soutěže, zaměření pozornosti). Současně však byla respondenty u kognitivních vlastností uváděna nejvyšši míra neporozumění těm položkám, které odkazují na mentální trénink a imaginaci. Právě položky z těchto dvou škál obsahovaly řadu termínů cizojazyčného původu.

Na základě těchto skutečností se domníváme, že z hlediska praktické uplatnitelnosti i lepších psychometrických vlastnosti je třeba vytvořit modifikovanou verzi OMSAT-3*, která nebude totožná s tou zahraniční. Domníváme se totiž, že ani zpřesněním překladu nemusí být vystihnut socio-kulturní rozdíl ve vnímání a porozumění termínů. Pro vznik české adaptace OMSAT-3* proto stanovujeme následující doporučení:

1. Bude zahrnovat všechny otázky, které se u české verze OMSAT-3 ukázaly jako vhodné pro tvorbu škál.

2. Některé mentální dovednosti budou uvedeny jejich definicí (mentální trénink, plánování soutěže a zvládání strachu). Tak zajistíme porozumění otázkám respondenty a bude to odpovídat struktuře starší verze dotazníku OMSAT-3 (Durrand-Bush, 1995).

3. Je potřeba rozebrat zbývající neadekvátní tvrzení a znovu je formulovat.

\section{ZÁVĚR}

Našim cílem bylo přeložit z angličtiny do češtiny dotazník OMSAT-3* (Ottawa Mental Skill Assessment Tool-3*, Durrand-Bush \& Salmela, 2001) a zahájit proces jeho standardizace. Pomocí opakovaného procesu translace a retranslace jsme vytvořili jeho českou verzi - Ottawský dotazník mentálních dovedností ve sportu-3*. Ten byl ověřován na třech výzkumných vzorcích za účelem potvrzení reliability jednotlivých škál a obsahové validity položek. Podařilo se však potvrdit reliabilitu jako vnitřní konzistence pouze u 7 ze 12 škál (stanovování cílů, odhodlání, sebedưvěra, aktivace, zaměreni pozornosti, plánování soutěže mentální trénink). U starší a sportovně zkušenější populace se potvrdila také vnitřní konzistence škály reakce na stres. Přes opakovaný proces translace a retranslace se však nepodařilo zajistit validitu všech položek dotazníku. Domníváme se, že některé položky dotazníku je velmi složité prrímo do českého jazyka přeložit s plným zachováním původního významu a zároveň s dobrou srozumitelností pro respondenta. Proto navrhujeme modifikaci dotazníku, aby byl lépe zohledněn socio-kulturní rozdíl mezi českou a kanadskou sportovní populaci.

Současně se domníváme, že současnou českou verzi dotazníku OMSAT-3* zatím nelze uplatnit jako standardizovaný nástroj pro praxi. Ve své aktuální podobě by měl sloužit pouze k výzkumným účelům či jako pilotní nástroj pro orientaci sportovním psychologům. Nicméně je důležitým podkladem a východiskem pro dokončení procesu jeho standardizace a vytvoření finální české verze dotazníku OMSAT-3*. 


\section{Literatura}

Abbott, A., \& Collins, D. (2004). Eliminating the Dichotomy Between Theory and Practicein Talent Identification and Development: Considering the Role of Psychology. Journal of Sports Sciences, 22, 395-408.

Baker, J., Schorer, J., \& Cobley, S. (2012). Talent identification and development in sport: Internationalperspectives. Abingdon, UK: Routledge.

Banville, D., Desrosiers, P., \& Genet-Volet, Y. (2000). Translating questionnaires and inventories using a cross-cultural translation technique. Journal of Teaching in Physical Education, 19, 374-387.

Blahutková, M., \& Pacholík, V. (2006). Psychologie sportu[Studijní text]. Retrieved (datum) from the World Wide Web: http:// www.fsps.muni.cz/czv/dokumenty/treneri/Psychologie_sportu_studi jni_text.pdf

Bota, J. D. (1993). Development of Ottawa Mental Skills Assessment Tool (OMSAT). [Unpublished master thesis]. Canada: University of Ottawa. Retrieved 2. 8. 2013 from the World Wide Web: https://www.ruor.uottawa.ca/handle/10393/6668.

Common European Framework of Reference for Languages CEFR) (2014) [On-line]. Retrieved (datum) from Cambridge ESOL on the World Wide Web: http://www.examenglish.com/CEFR/cefr.php

Craicun, M. (2009). Adaptation to Romanian Norms of the Ottawa Mental Skills Assessment Tool-3*(OMSAT-3*)[Unpublished manuscript]. Cluj: Babes-Bolyai University.

Craicun, M., Dobosi, S., \& Rusu, F. (2009). A Confirmatory factor analysis of the Ottawa Mental Skill Assessment Tool (OMSAT-3*) - Romanian Version.European Journal of Physical \& Health Education 2, 87-95.

Curtis, J. D. (1987). The mindset for winning. Lacrosse, Wl: Coulee Press.

Dias, C. S., Cruz, J. F. A., \& Fonseca, A. M. (2010). Coping strategies, multidimensional competitive anxiety and cognitive threat appraisal: Differences across sex, age and type of sport. Serbian Journal of Sport Sciences, 4(1), 23-31.

Durand-Bush, N. (1995). Validity and reliability of the Ottawa Mental Skills Assessment Tool (OMSAT-3). [Unpublished manuscript]. Canada, Ottawa: University of Ottawa. Retrieved 20. 10. 2013 from the World Wide Web: http://www.ruor. uottawa.ca/handle/10393/9738

Durand-Bush, N., \& Salmela, J. H. (2001). The development of talent in sport. Sport Psychologist, 20, 269-284.

Durand-Bush, N., Salmela, J. H., \& Green-Demers, I. (2001). The Ottawa Mental Skills Assessment Tool (OMSAT-3). The Sport Psychologist, 15, 1-19.

Ericsson, K. A., \& Faivre, I. A. (1988). What's exceptional about exceptional abilities? In I. K. Obler \& D. Fein (Eds.). The exceptional brain: Neuropsychology of talent. (pp. 436-473) New York: Guilford Press.

Fournier, J., Bernier, M., \& Durand-Bush, N. (2006). Version française du questionnaire Ottawa Mental Skills Assessement Tool. Retrieved 25. 11. 2013 from the World Wide Web: http://www.mindeval.com

Gould, D., Guinan, D., Greenleaf, C., Medbery, R., \& Peterson, K. (1999). Factors Affecting Olympic Performance: Perceptions of Athletes and Coaches from more and less Successful Teams. The Sport Psychologist, 13, 371-395.

Guelmami, N., Hamrouni, S., \& Agrébi, B. (2014). Psychological profiles of talented male youth athletes in team sports games. Journal of Physical Education and Sports Management, 5(1), 5-10.

Hammermeister, J., Pickering, M. A., \&Ohlson, C. J. (2009). Teaching mental skills for self-esteem enhancement in a military healthcare setting. Journal of Instructional Psychology, 36(3), 203-209. NY: Military Academy West Point.

Harris, D., \& Harris, B. (1984). The athlete's guide to sports psychology: Mental skills for physical people. New York: Leisure Press.

Horn, T. (Ed.). (2002). Advances in sport psychology (2nd ed.). Champaign, IL: Human Kinetics.

Hřebíčková, H. (2013). Mentální trénink v prípravě alpských lyžařů juniorů. Disertační práce, Univerzita Palackého v Olomouci, Fakulta tělesné kultury, Olomouc.

Kline, P. (1993). The handbook of psychological testing. London: Routledge.

Krane, V., \& Williams, J. M. (2010). Psychological Characteristics of Peak Performance. In J. M. Williams (Ed.). Applied Sport Psychology: Personal Growth to Peak Performance (6 $6^{\text {th }}$ Ed.). New York, NY: McGraw-Hill.

Lesyk, J. J. (1998). The nine mental skills of successful athletes. In Annual Conference of the Association for the Advancement of Applied Sport Psychology, Hyannis. MA.

Mahoney, M. J., Gabriel, T. J., \& Perkins, T. S. (1987). Psychological Skills and Exceptional Athletic Performance. The Sport Psychologist, 1, 181-199.

Noômen, G., Mohamed, J., Nasri, H., \& Brahim, A. (2015). Sensitivity, Internal Consistency and Factorial Structure of the Arabic Version of OMSAT-3. Advances in Physical Education, 5(1), 18

Orlick, T. (1992). The psychology of personal excellence. Contemporary Thought on Performance Enhancement, 1(1), 109-122.

Orlick, T. (1996). The wheel of excellence. Journal of Performance Education, 1, 3-18.

Orlick, T., \& Partington, J. (1988). Mental links to excellence. The Sport Psychologist, 2(2), 105-130.

Pashabadi, A., Shahbazi, M., Hoseini, S. M., Mokaberian, M., Kashanai, V., \& Heidari, A. (2011). The Comparison of mental skills in elite and sub-elite male and female volleyball players. Procedia-Social and Behavioral Sciences, 30, 1538-1540.

Salmela, J. H. (1992). The Ottawa mental skills assessment tool (OMSAT). Unpublished manuscript, University of Ottawa, Ottawa, Canada.

Salmela, J. H., Monfared, S. S., Mosayebi, F., \& Durand-Bush, N. (2009). Mental Skill Profiles and Expertise Levels of Elite Iranian Athletes. International Journal of SportPsychology, 40, 361-373.

Shahbazi, M., Rahimizadeh, M., Rajabi, M. R., \& Abdolmaleki, H. (2011). Mental and Physical Characteristics in Iranian Men's Handball National Team, Winner of Silver Medal in Asian Games-2010. Procedia-Social and Behavioral Sciences, 30, 2268-2271.

Schmidt, R. A. (1991). Motor learning and performance. Champaign, IL: Human Kinetics. 
Slepička, P., Hošek, V., \& Hátlová, B. (2006). Psychologie sportu. Praha: Univerzita Karlova, Karolinum.

Stevenson, M. (1999). The Use of Mental Skills by Male and Female Athletes. [Unpublished manuscript]. Canada: University of Ottawa.

Tod, D., Thatcher, J., Rahman, R., Holt, N., \& Lewis, R. (2012). Psychologie sportu. Grada.

Urbánek, T. (1997). Strukturální modelování v psychologii. Akademie věd České republiky, Psychologie.

Urbánek, T., Denglerová, D., \& Širůček, J. (2011). Psychometrika. Praha: Portál.

Vallerand, R. J. (1989). Toward a methodology for the transcultural validation of psychological questionnaires - Implications for Studies in the french language. Canadian Psychology-Psychologie Canadienne, 30(4), 662-680.

Vazini Taher, A., \& Shahbazi, M. (2013). Functional Capacities and Mental Skills Necessary for Expertise in Soccer. Iranian Journal of Health and Physical activity, 4(1), 44-50.

Vealey, R. S. (2007). Mental skills training in sport. In G. Tenenbaum \& R. Eklund (Eds.), Handbook of sport psychology (pp. 287-309), (3rd ed.). Chichester: John Wiley and Sons.

Vianna, J., \& Newton, S. (2005). OMSAT-3* - Ottawa Mental Skills Assessment Tool 3 - Português, Tradução/Outra.

Vičar, M., \& Válková, H., (2014). Identifikace sportovního talentu u dětí. Svět nadání, 3(2), 32-60.

Vičar, M., Protič, M., \& Válková, H. (2014). Sportovní nadání - psychologická perspektiva. Olomouc: Vydavatelství UP.

Vičar, M. (2016). Sportovní talent a standardizace Ottawského dotazníku mentálních dovedností ve sportu - OMSAT-3*. Disertační práce, Univerzita Palackého v Olomouci, Fakulta tělesné kultury, Olomouc.

Weinberg, R. S., \& Gould, D. (2011). Foundations of sport \& exercise psychology. Champaign, IL: Human Kinetics.

\section{Kontakt na autora:}

Mgr. Michal Vičar

Fakulta sportovních studií, Masarykova univerzita, Brno

vicar@fsps.muni.cz

Tel. 731268440

Vídeňská 12, Olomouc, 77900 